\title{
Mapping Mexican COVID-19 vulnerability at municipal scale $\hbar^{\star s}$
}

\section{Mapeo de la vulnerabilidad municipal mexicana para enfrentar la contingencia COVID-19}

\author{
Rainer Ressl*a, Carmen Luz Martínez ${ }^{\mathrm{a}}$, Miriam Elizabeth Piña Camacho ${ }^{\mathrm{a}}$, Florian Hruby*a,b , José Manuel Dávila Rosas ${ }^{\mathrm{a}}$, Manuel \\ Ernesto Rodríguez Huesca ${ }^{a}$, Raúl Jimenez-Rosenberg ${ }^{\mathrm{a}}$ \\ ${ }^{a}$ National Commission for the Knowledge and Use of Biodiversity (CONABIO). Insurgentes Sur 4903, Parques del Pedregal, Alcaldía de Tlalpan, Ciudad de \\ México. C.P. 14010 \\ ${ }^{b}$ University of Graz. Department of Geography and Regional Science. Universitätspl. 3, $8010 \mathrm{Graz}$
}

\begin{abstract}
This paper presents an interactive map related to the population vulnerability concerning COVID-19 at the municipal level for Mexico. A vulnerability index was modeled using seven socioeconomic/sociodemographic variables and one health-care related variable, all with relevance to a health contingency such as COVID-19. The resulting indicator expresses the municipal vulnerability to face a sanitary crisis such as COVID-19 in five categories. Data for each of the eight variables were first categorized in quintiles. A pairwise comparison matrix was used to weight these variables in relation to their estimated relevance for the municipal vulnerability. With respect to COVID-19 vulnerability, Mexican municipalities show the following results: 1.6\% (very low), 18.7\% (low), $46.6 \%$ (medium), $24.6 \%$ (high), $8.5 \%$ (very high). The map forms part of a dashboard providing daily information on the development of the pandemic in Mexico, and is complemented by a digital atlas visualizing information for each variable of the indicator.
\end{abstract}

Keywords: COVID19; vulnerability; municipal; visualization; dashboard

\section{Resumen}

Este artículo presenta un mapa interactivo relacionado con la vulnerabilidad de la población frente al COVID-19 a nivel municipal para México. El índice de vulnerabilidad se definió a partir de siete variables socioeconómicas / sociodemográficas y una variable relacionada con la capacidad hospitalaria, todas con relevancia para una contingencia de salud como COVID-19. El indicador resultante expresa la vulnerabilidad municipal para enfrentar una crisis sanitaria como COVID-19 en cinco categorías. Los datos de cada una de las ocho variables se categorizaron primero en quintiles. Se utilizó una matriz de comparación por pares para ponderar estas variables en relación con su relevancia estimada para la vulnerabilidad municipal. Con respecto a la vulnerabilidad COVID-19, los municipios mexicanos muestran los siguientes resultados: 1.6\% (muy baja), $18.7 \%$ (baja), $46.6 \%$ (media), $24.6 \%$ (alta), $8.5 \%$ (muy alta). El mapa forma parte de un tablero que brinda información diaria sobre el desarrollo de la pandemia en México y se complementa con un atlas digital que visualiza información para cada variable del indicador.

Palabras clave: COVID-19; vulnerabilidad; municipio; visualización; tablero

(c) R. Ressl, C. L. Martínez, M. E. Piña Camacho, F. Hruby, J. M. Dávila Rosas, M. E. Rodríguez Huesca, R. Jimenez-Rosenberg

This is an Open Access article distributed under the terms of the Creative Commons Attribution License (https://creativecommons.org/licenses/by-nc-sa/4.0/), which permits non-commencial sharing of the work and adaptions, provided the original work is properly cited and the new creations are licensed under identical terms.

Correos electrónicos: rainer.ressl@conabio.gob.mx, florian.hruby@uni-graz.at

\section{Introduction}

\subsection{Vulnerability and COVID-19}

The COVID-19 pandemic, caused by the virus SARS-CoV2 , has struck worldwide populations and national economies in an unprecedented way. The entire population can be identified as vulnerable to the new virus SARS-CoV-2, as no relevant immunity of the population to this new version of the coronavirus exists or is still unknown. Nevertheless, risk of infection and quality of possible medical treatment are not uniformly distributed across the population (Lourenço et al., 2020). Vulnerability to face COVID-19 has many dimensions. Thus, concep- 
tual and operational definitions and the methods and measurements of vulnerability differ with respect to scale and among different disciplines, including economics (e.g. asset-based), sociology, disaster management, environmental science, and health, among others (Alwang et al., 2001). Each discipline tends to view vulnerability in a slightly different manner. Efforts are underway attempting to measure vulnerability not only on a household level, but also on local, regional, and national scale. Naudé et al. (2009) suggest, that the measurement of vulnerability should ideally satisfy the following criteria: a) "predictive quality", b) a socially acceptable level of outcome, c) information on the causes of vulnerability and the relative importance of risk, d) referring to a particular cause of vulnerability, i.e. be hazard-specific, e) consider the dynamics of vulnerability (before, during, after), f) assessing a system's ways and means of coping with risk (resilience). The International Strategy for Disaster Reduction (ISDR) defines vulnerability as "the set of conditions and processes resulting from physical, social, economic, and environmental factors, which increase the susceptibility of a community to the impact of hazards" (ISDR, 2004).

The more socially focused view of Blaikie et al. (1994) defines vulnerability as the: "...set of characteristics of a group or individual in terms of their capacity to anticipate, cope with, resist and recover from the impact of a natural hazard. It involves a combination of factors that determine the degree to which someone's life and livelihood is at risk by a discrete and identifiable event in nature or society". As natural disasters or external shocks occur, households and social systems allow them to become (or not become) disasters through their response and preparedness. In this context, in our case we can define vulnerability as a combination of social factors and the preparedness of Mexico's welfare systems, in particular the health sector, to respond to the COVID-19 crisis. We focus on a regional (meso) scale showing vulnerability to a natural hazard (virus SARS$\mathrm{CoV}-2$ ) at municipal level. This scale is sufficiently detailed to demonstrate regional differences and to provide information about vulnerability to COVID-19 with appropriate detail for decision-makers.

\subsection{Data}

The socioeconomic and sociodemographic data corresponds to the 2015 Intercensal Survey carried out by the National Institute of Statistics and Geography (INEGI, 2019). Following data was obtained: population aged 60 years and older, migration according to the place of residence five years before, population that speaks an indigenous language, employed population with income of up to a minimum wage, and private homes with piped water from the public network. Indicators used as additional variables to construct the vulnerability index, such as the condition of poverty for the years 2010 and 2015 and the

\footnotetext{
${ }^{1} \mathrm{~A}$ person is in a situation of poverty having at least one social deprivation (in the indicators of educational backwardness, access to health services, access
}

marginalization of the population (2015), were developed by the National Council for the Evaluation of Social Development Policy (CONEVAL, 2018) and the National Population Council (CONAPO, 2019a; CONAPO, 2019b), respectively. Further, health sector related information on the availability of hospital beds for the year 2018 was provided by the Mexican Ministry of Health (Secretaría de Salud).

\section{Methods}

\subsection{Variable selection}

The objective of this study was to develop a simple indicator for vulnerability using the most relevant variables with available data at the municipal level. As mentioned before, vulnerability facing COVID-19 has many aspects and can be investigated in different ways by various disciplines. In a first step, we identified three main dimensions with importance for COVID19 vulnerability for Mexico: demographic, socio-economic, and health. The vulnerability index should therefore reflect relevant demographic aspects (i.e. age), as well as information on the social and economic situation of households (i.e. poverty, housing characteristics) and on the available infrastructure of the health sector (proxy: hospital beds). To avoid the combination of data available at different geographic scales (e.g. municipal vs state), we restricted the selection of variables to those, where information was available at the municipal level. Therefore, crucial information about health preconditions of the population with negative implications towards COVID-19 resilience, such as diabetes rate, obesity, respiratory diseases, and general morbidity did not form part of the analysis as data was not uniformly available for all municipalities, but rather on the state level.

Applying an interactive consultation among a group of analysts and additionally of experts of the mentioned disciplines, the following eight variables were selected according to their importance towards the vulnerability of the population to face a health contingency (seven socio-economic variables and one variable that shows the hospitalization capacity of a medical unit, expressed as the number of beds per 10,000 inhabitants): (1) percentage of the population aged 60 years and older, (2) percentage of the population aged 5 years and older with place of residence in a specific municipality in 2015 , but resided in another municipality of the same state in 2010, (3) percentage of the population living in poverty, (4) percentage of the total population that speaks an indigenous language, (5) percentage of the employed population with an income of up to a minimum wag $\mathrm{g}^{2}$ (6) percentage of private homes that receive piped water from the public network, (7) degree of marginalization

to social security, quality and spaces of housing, basic services in housing and access to food) and if the income is insufficient to purchase the goods and services the person requires to satisfy the food and non-food needs. (CONEVAL, 2010)

${ }^{2}$ INEGI: Minimum wage 2020: 123.22 pesos per day, equivalent to 5.7 USdollars (Sept. 2020) 
and (8) hospital beds per 10,000 inhabitants at the municipal level in 2018. The considered variables characterize the level of well-being, the dimension of deprivation, the economic capacity, and provide an approximation for mobility within municipalities and the capacity of a medical unit to take care of this health contingency.

\subsection{Indicator construction}

There are multiple ways to construct an indicator related to vulnerability. Tate (2012) defines three principal social vulnerability index designs: deductive, hierarchical, and inductive and applies global sensitivity analysis to validate the different methods. In our case, we opted for the deductive method due to a rather small number of variables in the analysis, combined with an approach to define the weights of each variable as applied in an analytical hierarchy process (Saaty, 1977). Vulnerability was considered as the diminished capacity of the municipality to face and resist the effects of a health contingency and to recover from it (Feito, 2007). The method used to develop this indicator was a linear weighted combination of the selected variables considering the weight for each variable derived from a pairwise comparison matrix. In a first step, data of the selected variables were classified in quintiles as shown in Table 1 .

Table 1 is arranged in such a way that quintile 1 always expresses the best characteristic, condition or service for the population while quintile 5 reflects the worst condition. Subsequently, for the normalization of the table, a fractional value was assigned to each quintile: 0.2 for $1,0.4$ for $2,0.6$ for $3,0.8$ for 4 , and 1 for 5 . After applying the weights for each variable, this normalization enables the indicator to end up in the range $0-1$, which allows for an easier interpretation of the indicator.

\subsection{Variable weighting scheme}

Not all variables comprising a vulnerability indicator necessarily have the same importance. Their individual importance can be expressed by assigning a weight to each variable. There are several methods to find the vector of the weights of elements/variables. We used the method of Saaty (1977) where the user must compare variables/factors using an equidistant verbal scale within a comparison matrix of the elements. The vector of weights is calculated as the normalized eigenvector of the pairwise comparison matrix. The paired matrix is characterized by the following: (1) diagonal values are 1; and (2) the values of the factors (in our case the variables in table 1) or elements of the matrix are $a_{i j}=1 / a_{i j}$. In our case, we use a 9-point scale for the subjective evaluation of the variables, where 1 means that the variable $\mathrm{x}$ has the same importance (equal) as the variable y. The positive scale ( 1 - 9) expresses the degree of higher importance of the variable compared to the other, while the values $1 / 3-1 / 9$ show the degree of less importance. An example of a matrix with 9 variables can be seen in Figure 1 .

Five analysts filled the table based on their experience on the subject with their "best educated guess". The results (weights per variable) of each analyst can be seen in Figure 2.

Table 1. Categorization of variables based on data from INEGI, CONAPO, CONEVAL and the Ministry of Health / Tabla 1. Categorización de variables basada en datos del INEGI, CONAPO, CONEVAL y la Secretaría de Salud

\begin{tabular}{|c|c|c|c|c|c|c|}
\hline \multicolumn{7}{|c|}{ Data range classification of variables } \\
\hline \multirow[b]{2}{*}{ No. } & \multirow[b]{2}{*}{ Variable } & \multicolumn{5}{|c|}{ Quintiles } \\
\hline & & 1 & 2 & 3 & 4 & 5 \\
\hline 2 & $\begin{array}{l}\text { Percentage of the population aged } 5 \text { years } \\
\text { and older with place of residence in a } \\
\text { specific municipality in } 2015 \text {, but resided in } \\
\text { another municipality of the same state in } \\
2010\end{array}$ & Less than $12.0 \%$ & $12.1-24.0 \%$ & $24.1-36.0 \%$ & $36.1-48.0 \%$ & $48.1-61.0 \%$ \\
\hline 3 & $\begin{array}{l}\text { Percentage of the population living in } \\
\text { poverty, } 2015\end{array}$ & Less than $20 \%$ & $20.1-40.0 \%$ & $40.1-60.0 \%$ & $60.1-80.0 \%$ & $80.1-100.0 \%$ \\
\hline 4 & $\begin{array}{l}\text { Percentage of the total population that } \\
\text { speaks an indigenous language, } 2015\end{array}$ & Less than $20 \%$ & $20.1-40.0 \%$ & $40.1-60.0 \%$ & $60.1-80.0 \%$ & $80.1-100.0 \%$ \\
\hline 7 & Degree of marginalization (Index), 2015 & $\begin{array}{l}-2.228 \text { to }-1.080 \\
\quad \text { (Very low) }\end{array}$ & $\begin{array}{l}-1.068 \text { to }-0.503 \\
\text { (Low) }\end{array}$ & $\begin{array}{l}-0.495 \text { to } 0.077 \\
\quad \text { (Medium) }\end{array}$ & $\begin{array}{l}0.087-1.229 \\
\quad \text { (High) }\end{array}$ & $\begin{array}{l}1.237-5.027 \\
\text { (Very high) }\end{array}$ \\
\hline 8 & $\begin{array}{l}\text { Number of beds per } 10 \text { thousand } \\
\text { inhabitants at municipal level, } 2018\end{array}$ & $65-371$ & $44-64$ & $29-43$ & $15-28$ & $0-14$ \\
\hline
\end{tabular}




\begin{tabular}{|c|c|c|c|c|c|c|c|c|}
\hline \multicolumn{9}{|c|}{ PAIRWISE COMPARISON MATRIX } \\
\hline & $\begin{array}{l}\text { Population } \\
\text { (age) }\end{array}$ & Migration & Poverty & $\begin{array}{l}\text { Indigenous } \\
\text { population }\end{array}$ & Income & $\begin{array}{l}\text { Water } \\
\text { availability }\end{array}$ & Marginalization & $\begin{array}{l}\text { Medical } \\
\text { services }\end{array}$ \\
\hline Population (age) & 1 & --- & --- & --- & --- & --- & --- & --- \\
\hline Migration & $1 / 5$ & 1 & --- & --- & --- & --- & --- & --- \\
\hline Poverty & 1 & 4 & 1 & --- & -- & --- & --- & -- \\
\hline $\begin{array}{l}\text { Indigenous } \\
\text { population }\end{array}$ & $1 / 4$ & 3 & 1 & 1 & -- & -- & -- & -- \\
\hline Income & $1 / 2$ & 4 & $1 / 2$ & 3 & 1 & --- & --- & --- \\
\hline $\begin{array}{l}\text { Water } \\
\text { availability }\end{array}$ & $1 / 3$ & 5 & $1 / 3$ & 4 & 1 & 1 & -- & -- \\
\hline Marginal ization & $1 / 4$ & 4 & $1 / 2$ & 4 & 2 & 3 & 1 & -- \\
\hline Medical services & 1 & 6 & 4 & 4 & 5 & 7 & 5 & 1 \\
\hline \multicolumn{9}{|c|}{ Pairwise comparison with a 9-point rating scale } \\
\hline $1 / 9$ & $1 / 7$ & $1 / 5$ & $1 / 3$ & 1 & 3 & 5 & 7 & 9 \\
\hline Extremely & Very strongly & Strongly & Moderate & ly Equally & Moderately & y Strongly & Very strongly & Extremely \\
\hline \multicolumn{5}{|c|}{ LESS IMPORTANT } & \multicolumn{4}{|c|}{ MORE IMPORTANT } \\
\hline
\end{tabular}

Figure 1: Example of a pairwise comparison matrix with a 9-point rating scale / Ejemplo de una matriz de comparación por pares con una escala de evaluación de 9 puntos

Individual weights for all variables sum up to 1 . Together with the normalized categorization described before, where each fractional value for any variable will be multiplied with the respective weight, the vulnerability index ends up in the range 0 to 1 . The consistency of variable comparisons within each matrix can be calculated for each analyst and expresses the degree of consistency of the variable evaluation in comparison to a random pairwise comparison. Saaty (1977) shows that this pairwise comparison of variables for weight definition works fine up to a number of $7 \pm 2$ variables, as the judgment of variable comparisons becomes increasingly more difficult with a larger number of variables. The consistency/inconsistency of the matrix can be calculated using the principal eigenvector/eigenvalue approach and deriving a Consistency Index $(C I)$, with $C I=\left(\lambda_{\max }-n\right) /(n-1)$, and $\lambda_{\max }=\max$ eigenvalue of the matrix, and $n=$ the number of variables of the matrix.

After deriving the individual weights for all variables, the results were ranked with respect to their values. To get the final weightings for all variables and to obtain a consolidated measure of the pairwise comparisons of all analysts, the individual weights for each variable were averaged and ranked as shown in Figure 2. It can be noted that the health care variable (proxy: available beds) was ranked number 1 among all analysts, which resulted also in the highest importance within the overall ranking (weight: 0.3424). Socioeconomic and sociodemographic variables and their importance were estimated quite differently among the analysts. Overall, household income was rated second most important (weight: 0.14948), followed by marginalization (weight: 0.10664), poverty (weight: 0.09308), presence of indigenous population (weight: 0.09072), water availability in households (weight: 0.0892), population aged 60 years and over (weight 0.07828) and finally migration (weight 0.05022).

Each of the derived weights was multiplied with the fractional values derived from table 1 , to obtain the final map by a weighted linear combination of all variables at the municipal level.

\section{Results}

\subsection{Vulnerability degree}

After categorizing each variable into quintiles and subsequent weighting, the vulnerability index results in the range from $0-1$. The indicator reflects the five degrees of vulnerability in which the country's municipalities are classified and which are shown in Table 2.

The characteristics of each vulnerability degree can be summarized as follows:

Very low vulnerability. In this category fall $1.6 \%$ (38) of the country's municipalities. The majority of municipalities show less than $24 \%$ of the population of age 60 years or older, less than $12 \%$ of the population changes their place of residence temporarily. These municipalities present the lowest levels of poverty, combined $61 \%$ in the two lowest poverty categories. The majority of the municipalities have less than $20 \%$ indigenous population. Less than $54 \%$ of the employed population has a daily income of up to 1 minimum wage. $97 \%$ of all municipalities receive water from the public network with $80-100 \%$ of households connected. Marginalization is medium, low or very low. Only one municipality accounts for 371 hospital beds, 7 can provide between 69 and 100 beds, the rest of the municipalities have between 15 and 64 registered beds in their medical units for every 10,000 inhabitants.

Low vulnerability. In this category, $18.7 \%$ (460) of the country's municipalities can be summarized. Up to $32 \%$ of their population is aged 60 years and older and up to $48 \%$ of the population changes their place of residence temporarily. Although all poverty levels are present, $60 \%$ of the municipalities fall in the two lowest poverty categories. In all municipalities, indigenous populations show presence, some even up to $100 \%$ of the total population. In some municipalities, up to $100 \%$ of the employed population has an income of only 1 minimum wage. $97 \%$ of all municipalities receive water from the public network, with $60-100 \%$ of all households connected. All levels of marginalization are present. Only 1 municipality has 300 hospital beds, another 171 beds, 8 can provide between 65 to 107 beds, and the rest of the municipalities have less than 64 beds in their medical units for every 10,000 inhabitants.

Medium vulnerability. In this category, there are $46.6 \%$ $(1,145)$ of the country's municipalities. Up to $42 \%$ of the population is 60 years or older. Up to $61 \%$ of the population changes their place of residence temporarily. All levels of poverty are present, but $87 \%$ (998) of all municipalities fall in the third and fourth quintiles of poverty categories. In all municipalities indigenous populations are present, in some up to $100 \%$ of the municipality's population. Up to $100 \%$ of the employed population has an income of up to only 1 minimum wage. $92 \%$ of all municipalities receiving water from the public network fall in the first and second quintiles (with $60-100 \%$ of all households 


\begin{tabular}{|c|c|c|c|c|c|c|c|c|c|}
\hline \multicolumn{3}{|c|}{ Analyst 1} & \multicolumn{3}{|c|}{ Analyst 2} & \multicolumn{3}{|c|}{ Analyst 3} & \\
\hline Variable & Weight & Rank & Variable & Weight & Rank & Variable & Weight & Rank & \\
\hline Population & 0.0248 & 7 & Population & 0.2032 & 2 & Population & 0.0168 & 8 & \\
\hline Migration & 0.1236 & 4 & Migration & 0.026 & 8 & Migration & 0.0313 & 7 & \\
\hline Poverty & 0.0745 & 5 & Poverty & 0.1313 & 3 & Poverty & 0.1138 & 5 & \\
\hline Indigen. Pop. & 0.0523 & 6 & Indigen. Pop. & 0.0519 & 7 & Indigen. Pop. & 0.1188 & 4 & \\
\hline Income & 0.2268 & 2 & Income & 0.0782 & 5 & Income & 0.1541 & 3 & \\
\hline Water & 0.0303 & 8 & Water & 0.0766 & 6 & Water & 0.2251 & 2 & \\
\hline Marginalization & 0.1463 & 3 & Marginalization & 0.1103 & 4 & Marginalization & 0.09 & 6 & \\
\hline Medical Serv. & 0.3213 & 1 & Medical Serv. & 0.3226 & 1 & Medical Serv. & 0.2502 & 1 & \\
\hline \multicolumn{3}{|c|}{ Analyst 4} & \multicolumn{3}{|c|}{ Analyst 5} & \multicolumn{3}{|c|}{ All analysts } & \\
\hline Variable & Weight & Rank & Variable & Weight & Rank & Variable & Sum & Average & Rank \\
\hline Population & 0.1263 & 4 & Population & 0.0203 & 8 & Medical Serv. & 1.712 & 0.3424 & 1 \\
\hline Migration & 0.0393 & 8 & Migration & 0.0309 & 6 & Income & 0.7474 & 0.14948 & 2 \\
\hline Poverty & 0.0553 & 7 & Poverty & 0.0905 & 4 & Marginalization & 0.5332 & 0.10664 & 3 \\
\hline Indigenous Pop. & 0.1544 & 2 & Indigenous Pop. & 0.0762 & 5 & Poverty & 0.4654 & 0.09308 & 4 \\
\hline Income & 0.1267 & 3 & Income & 0.1616 & 2 & Indigenous Pop. & 0.4536 & 0.09072 & 5 \\
\hline Water & 0.0922 & 5 & Water & 0.0218 & 7 & Water & 0.4460 & 0.0892 & 6 \\
\hline Marginalization & 0.0874 & 6 & Marginalization & 0.0992 & 3 & Population & 0.3914 & 0.07828 & 7 \\
\hline Medical Serv. & 0.3183 & 1 & Medical Serv. & 0.4996 & 1 & Migration & 0.2511 & 0.05022 & 8 \\
\hline
\end{tabular}

Figure 2: Individual results (weights) of the evaluation of the variables by each analyst / Resultados individuales (importancia) de la evaluación de variables por cada analista

connected). All levels of marginalization are present. All municipalities have less than 64 hospital beds available for every 10,000 inhabitants in their medical units, except for one municipality which has 65 beds.

High vulnerability. In this category fall $24.6 \%$ (604) of the country's municipalities. Up to $42 \%$ of the population is 60 years or older. Up to $24 \%$ of the population changes the place of residence temporarily. $98 \%$ percent of the population live in conditions of poverty (combined 4th and 5th quintile). All municipalities have indigenous populations, in some up to $100 \%$. Similarly, up to $100 \%$ of the employed population has an income of up to only 1 minimum wage. Water availability varies significantly among municipalities. Only $75 \%$ of all municipalities are in the highest category, with $80-100 \%$ of all households connected to the public network. Regarding the condition of marginalization, all four levels are present: low, medium, high, and very high. These municipalities show less than 43 hospital beds in their medical units for every 10,000 inhabitants.

Very high vulnerability. $5.5 \%$ (210) of the country's municipalities are in this category. Up to $42 \%$ of the population has an age of 60 years and over. Less than $12 \%$ of the population changes the place of residence temporarily. The population lives in poverty. 99\% (207) of these municipalities can be found in the highest category of poverty (quintile 5 or $80-100 \%$ ). In all municipalities there is a presence of indigenous population, in some up to $100 \%$. Up to $100 \%$ of the employed population has an income of up to only 1 minimum wage. Water availability varies significantly among municipalities. Only $60 \%$ of all municipalities are in the highest category, with $80-100 \%$ of all households connected to the public network. Municipalities show high and very high marginalization. These municipalities have between 0 to 43 hospital beds available in their medical units for every 10,000 inhabitants.

The above categories are visualized finally as the vulnerability map facing COVID-19 at the municipal level (Figure 3).

From the spatial distribution patterns of the categories we can note, that the high and very high vulnerability classes are more present in municipalities in the southern and southeastern states of the country, namely in the states of Guerrero, Oaxaca, Chiapas, and in the states of the Peninsula de Yucatan. Most of these states have lower developed health care systems in comparison with the rest of the country. In addition, these states usually show high marginalization, poverty, and low income of the population. The combination of these factors result in high vulnerability values due to the applied weighting scheme.

Table 2 illustrates the population distribution within the dif-

Table 2. Classification of municipal vulnerability degree and affected population / Tabla 2. Clasificación del grado de vulnerabilidad municipal y población afectada

\begin{tabular}{|c|c|c|c|c|c|}
\hline $\begin{array}{l}\text { Index } \\
\text { Interval }\end{array}$ & Vulnerability & Municipality & Percentage & $\begin{array}{l}\text { Population } \\
\text { (2015) }\end{array}$ & $\begin{array}{c}\text { Population of } 60 \text { years } \\
\text { and older (2015) }\end{array}$ \\
\hline $0.22-0.40$ & Very low vulnerability & 38 & 1.6 & $6,289,501$ & 892,687 \\
\hline $0.53-0.64$ & Medium Vulnerability & 1,145 & 46.6 & $36,659,633$ & $3,937,784$ \\
\hline $0.65-0.76$ & High vulnerability & 604 & 24.6 & $7,985,112$ & 890,040 \\
\hline $0.77-0.88$ & Very high vulnerability & 210 & 8.5 & $2,582,309$ & 229,881 \\
\hline
\end{tabular}




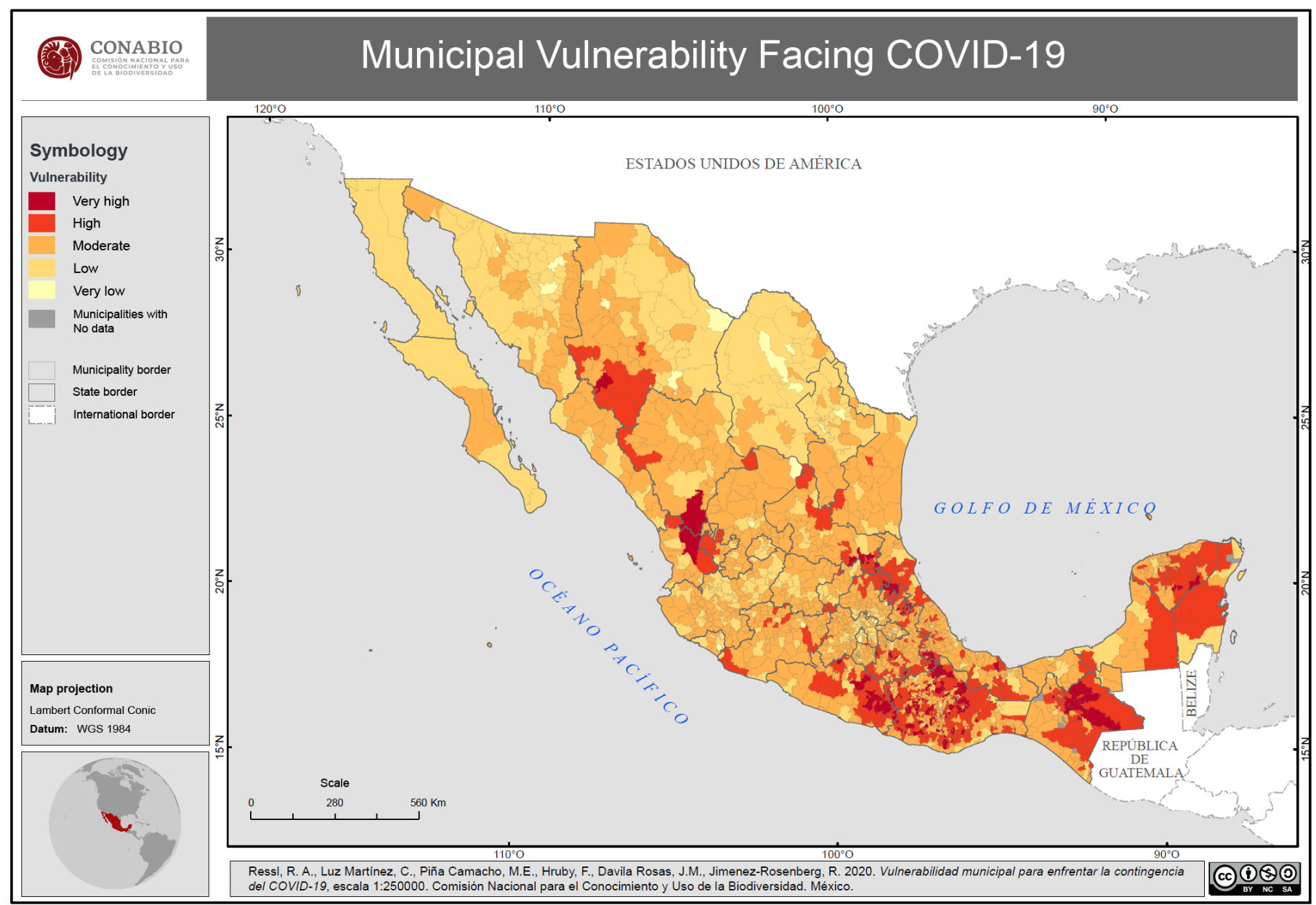

Figure 3: Degree of Mexican municipal vulnerability facing COVID-19 / Grado de vulnerabilidad municipal, en México, frente a COVID-19

ferent vulnerability classes for Mexico. Low and very low vulnerability of municipalities can be found predominantly in the northern portion of the country, representing $20.3 \%$ or $498 \mathrm{mu}-$ nicipalities. A population of 66 million falls within the class "low vulnerability", whereas only approximately 6.3 million people show a "very low vulnerability". Medium vulnerable municipalities can be found all over the country with a slight predominance in the center portions of Mexico. In total, 36.56 million people are classified under this category, living in 1,145 municipalities (46.6\%). "High vulnerable" population sums up to almost 8 million, and very high vulnerability can be assigned to a population of almost 2.6 million. Within these critical vulnerability classes, 890,040 people are 60 years and older and show high vulnerability and 229,881 people are characterized by a very high vulnerability.

Comparing visually our results with a vulnerability map generated simultaneously by the Institute of Geography of UNAM (Lastra et al., 2020) we find very similar distribution patterns for the most vulnerable parts of the country. Both maps differ by the number of variables used (UNAM, 17 variables) and the weighting method, as well as by the number of vulnerability categories derived. Therefore, statistics on population distri- bution concerning their vulnerability as well as the degree of municipal vulnerability cannot be compared directly.

\section{Publication}

\subsection{Indicator publication as part of an interactive dashboard}

During the COVID-19 pandemic, multiple information platforms have been developed to provide close to real-time information to the public. Many of these platforms, including our dashboard, were developed on ESRI's ArcGIS online technology offering a user-friendly and fast visualization of dynamic data in the form of interactive dashboards (ESRI, 2020b). One of the first of this kind to publish daily COVID-19 data was developed by the Johns Hopkins University, providing detailed information for the United States and the entire world (JHU, 2020; Dong et al., 2020). In Mexico, several institutions published almost simultaneously similar dashboards to provide COVID-19 relevant information in particular for Mexico. The Mexican government provides daily information through its official COVID-19 webpage (Gobierno de la Ciudad de México, 2020), supported also by dashboard developments of the Center for 
Research in Geography and Geomatics (CentroGeo, 2020). Besides, several national universities complement these existing efforts with dashboards with relevant information on health and socioeconomic/demographic aspects, such as the "Centro de Investigaciones en Geografía Ambiental" of the National Autonomous University of México (CIGA-UNAM, 2020).

The vulnerability index discussed in this paper is part of CONABIO's interactive dashboard providing daily information on COVID-19 development at the municipal and state levels (See dashboard). The user can examine each municipality, and information is provided in the popup window on the degree of vulnerability and the respective indicator value, as displayed in Figure 4 (CONABIO, 2020b). This state and municipality scale focused dashboard is complemented by a similar dashboard providing daily information for Mexico City at municipal (alcaldía) and city district level (CONABIO, 2020c).

\subsection{Atlas}

Besides the mentioned dashboards, COVID-19 information at national scale is provided within an interactive digital atlas linked to the primary dashboard (CONABIO, 2020a). This atlas presents different variables that help to identify the living condition and socioeconomic situation of the population of each municipality including the variables used to calculate the degree of vulnerability. The atlas provides the user with data on population and migration, health and nutrition, poverty, housing, and socioeconomic characteristics at municipality level. Data can be downloaded in different formats (such as shapefile, csv, $\mathrm{kml}$ ) and is complemented by a comprehensive document (pdf) that integrates ten additional topics (including information on the environment, biodiversity, economy, and production, as well as its respective base map) with more disaggregated data from different years, thus showing a very complete panorama for all municipalities of the country. To synthesize and visualize the COVID-19 relevant data which was used for the vulnerability index for each municipality, an interactive infographic was generated which can be displayed on demand on the main menu bar selecting the respective municipality. Each infographic also displays the calculated vulnerability level. All infographics were produced using ESRI's ArcGIS Business Analyst technology (ESRI, 2020a).

\section{Conclusions}

There are multiple ways to construct a municipality vulnerability index for COVID-19. This article presents a vulnerability index for COVID-19 at municipal level based on socioeconomic/sociodemographic and health infrastructure data. Our results illustrate that the majority of the municipalities show medium vulnerability facing COVID-19 (46.6\%). High (24.6\%) and very high vulnerable municipalities $(8.5 \%)$ can be found primarily in the southern and south-eastern parts of the country

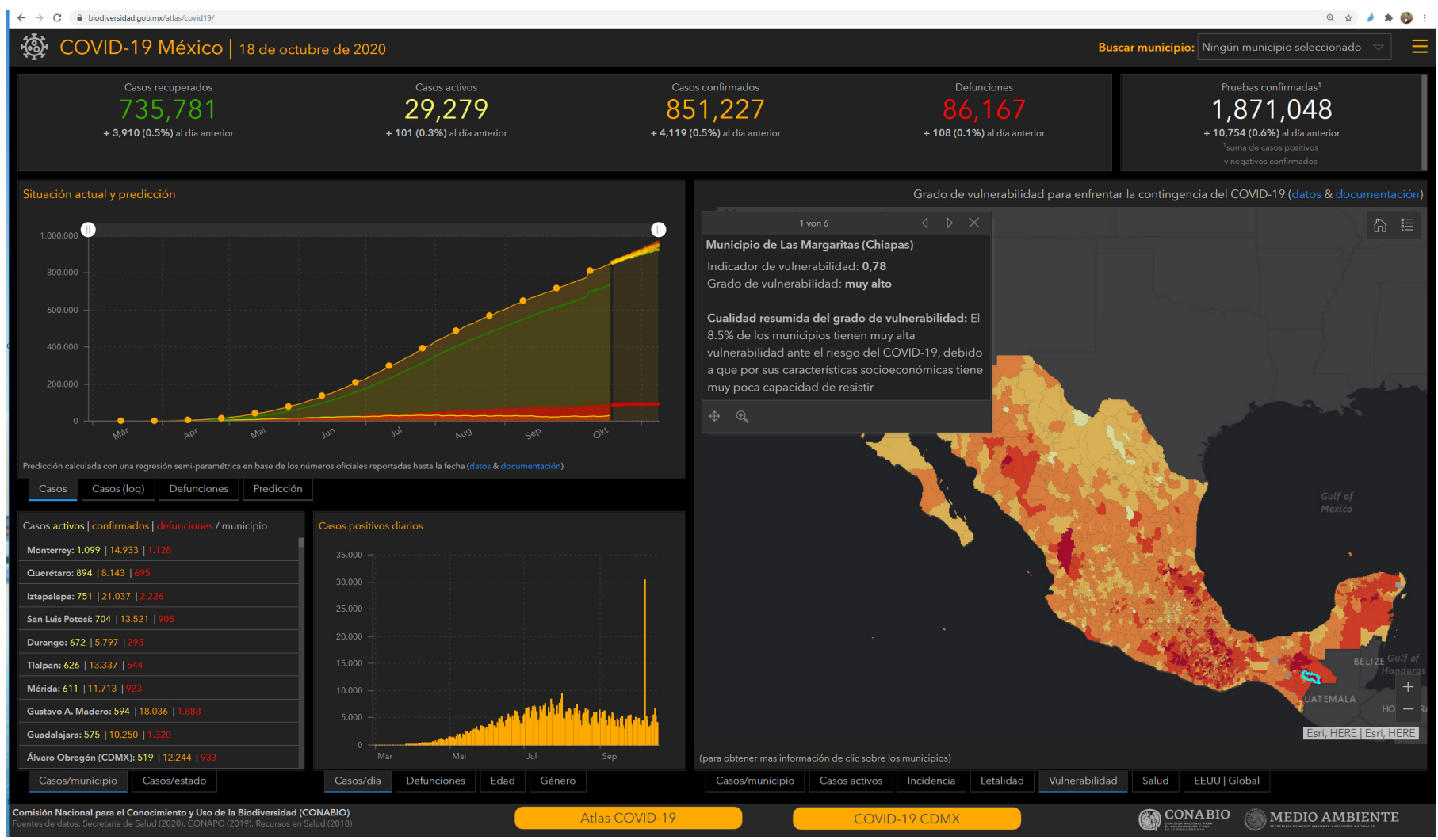

Figure 4: Municipal vulnerability map implemented in interactive COVID-19 dashboard / Mapa de vulnerabilidad municipal ante COVID-19, implementado en un tablero interactivo 
whereas municipalities with low (18.7\%) and very low vulnerability $(1.6 \%)$ are largely represented in the northern and northwestern regions of Mexico.

Validation of the vulnerability assessment proves to be complicated, as reported data on mortality or infection numbers are most likely inaccurate in terms of completeness and spatial representation. A direct comparison of these numbers (or other derived indicators) may therefore not reflect the modelled vulnerability conditions. As part of our study, we will validate the vulnerability assessment as soon as more reliable data on mortality at municipal level will be available hopefully after the end of the pandemic.

Nevertheless, the demonstrated vulnerability index provides useful information for decision-makers during a sanitary crisis such as COVID-19 to better prepare municipal infrastructure (e.g. hospital beds) and population for future pandemics.

\section{Funding}

The authors received no financial support for the research, authorship, and/or publication of this article.

\section{References}

Alwang, J., Siegel, P. B., Jorgensen, S.L., 2001. Vulnerability: A view from different disciplines. SP Discussion paper No. 0115/23304, World Bank Series.

Blaikie, P., Cannon, T., Davis, I., Wisner, B., 1994. At Risk: Natural Hazards, People's Vulnerability and Disasters. Routledge, https://doi.org/10.4324/9780203714775.

Centro de Investigaciones en Geografía Ambiental (CIGA), UNAM, 2020. Plataforma de información geográfica de la UNAM sobre COVID-19 en México. [Online]. https://covid19.ciga.unam.mx/ (Accessed: 20 October 2020).

Centro de Investigación en Ciencias de Información Geoespacial (CentroGeo), 2020. Covid-19 CDMX. [Online]. https://cdmx.dash.covid19.geoint.mx/ (Accessed: 20 October 2020).

Consejo Nacional de Evaluación de la Política de Desarrollo Social (CONEVAL), 2018. Anexo estadístico de pobreza a nivel municipio 2010 y 2015. [Data set]. https://www.coneval.org.mx/medicion/paginas/ae_pobreza_municipal.aspx (Accessed: 30 november 2018).

Consejo Nacional de Población (CONAPO), 2019a. Indices de marginación por municipio, 1990-2015. [Data set]. http://www.conapo.gob.mx/ES/CONAPO/Datos_Abiertos_del_Indice_de_ Marginacion (Accessed: 14 january 2019).

Consejo Nacional de Población (CONAPO), 2019b. Proyecciones de la Población de México y de las Entidades Federativas, 20162050. [Data set]. https://datos.gob.mx/busca/dataset/proyecciones-de-lapoblacion-de-mexico-y-de-las-entidades-federativas-2016-2050 (Accessed: 8 april 2020).

Dong, E., Du, H., Gardner, L., 2020. An interactive web-based dashboard to track COVID-19 in real time. The Lancet Infectious Diseases 20 (5), 533534, https://doi.org/10.1016/S1473-3099(20)30120-1.
Environmental Systems Research Institute (ESRI), 2020a. ArcGIS Business Analyst. [Online]. https://www.esri.com/en-us/arcgis/products/arcgisbusiness-analyst/overview (Accessed: 20 October 2020).

Environmental Systems Research Institute (ESRI), 2020b. ArcGIS Dashboards. [Online]. https://www.esri.com/en-us/arcgis/products/arcgisdashboards/overview (Accessed: 20 October 2020).

Feito, L., 2007. Vulnerabilidad. Anales del Sistema Sanitario de Navarra 30 (3), $7-22$.

Gobierno de la Ciudad de México, 2020. COVID-19. [Online]. https://covid19.cdmx.gob.mx/ (Accessed: 20 October 2020).

Instituto Nacional de Estadística y Geografía (INEGI), 2019. Tabulados predefinidos encuesta intercensal 2015. [Data set]. https://www.inegi.org.mx/programas/intercensal/2015/default.html\#tabulados (Accessed: 6 november 2018).

International Strategy for Disaster Reduction (ISDR), 2004. Living with Risk: A Global Review of Disaster Reduction Initiatives. United Nations.

Johns Hopkins University, 2020. Coronavirus Resource Center. [Online]. https://coronavirus.jhu.edu/map.html (Accessed: 20 October 2020).

Lourenço, J., Pinotti, F., Thompson, C., Gupta, S., 2020. The impact of host resistance on cumulative mortality and the threshold of herd immunity for SARS-CoV-2. medRxiv, https://doi.org/10.1101/2020.07.15.20154294.

National Commission for the Knowledge and Use of Biodiversity (CONABIO), 2020a. Atlas for COVID-19 for Mexico at state and municipal scale. [Online]. http://ssig.conabio.gob.mx/JavaBridge/covid19/temas/Pm/index.html (Accessed: 20 October 2020).

National Commission for the Knowledge and Use of Biodiversity (CONABIO), 2020b. Interactive dashboard for COVID19 for Mexico at state and municipal scale. [Online]. https://www.biodiversidad.gob.mx/atlas/covid19/(Accessed: 20 October 2020).

National Commission for the Knowledge and Use of Biodiversity (CONABIO), 2020c. Interactive dashboard for COVID-19 for Mexico-City at municipal and city-district scale. [Online]. https://www.biodiversidad.gob.mx/atlas/covid19/cdmx.html (Accessed: 20 October 2020).

Naudé, W., Santos-Paulino, A. U., McGillivray, M., 2009. Measuring Vulnerability: An Overview and Introduction. Oxford Development Studies 37 (3), 183-191, https://doi.org/10.1080/13600810903085792.

Saaty, T. L., 1977. A scaling method for priorities in hierarchical structures. Journal of Mathematical Psychology 15 (3), 234-281, https://doi.org/10.1016/0022-2496(77)90033-5.

Secretaria de Salud, 2020. Recursos de salud 2018. [Data set]. http://www.dgis.salud.gob.mx/contenidos/basesdedatos/da_recursos_gobmx .html (Accessed: 7 april 2020).

Suárez Lastra, M., Valdés González, C., Galindo Pérez, M., Salvador Guzmán, L., Ruiz Rivera, N., Alcántara-Ayala, I., López Cervantes, M., Rosales Tapia, A., Lee Alardin, W., Benítez Pérez, H., Juárez Gutiérrez, M. del C., Bringas López, O., Oropeza Orozco, O., Peralta Higuera, A., Garnica-Peña, R., 2020. Índice de vulnerabilidad ante el COVID-19 en México. Investigaciones GeográficasHttps://doi.org/10.14350/rig.60140.

Tate, E., 2012. Social vulnerability indices: a comparative assessment using uncertainty and sensitivity analysis. Natural Hazards 63 (2), 325-347, https://doi.org/10.1007/s11069-012-0152-2.

This article accompanies the following material:

HTML: $\quad$ https://doi.org/10.22201/igg.25940694e.2020.2.79

Dashboard: https://doi.org/10.22201/igg.25940694e.2020.2.79.166 